\section{ФОТОННЫЙ КОМПЬЮТЕР:}

\section{СТРУКТУРА И АЛГОРИТМЫ, ОЦЕНКИ ПАРАМЕТРОВ}

\author{
С.А.Степаненко, д.ф.- м.н., ssa@vniief.ru; Российский \\ федеральный ядерный центр - Всероссийский НИИ \\ экспериментальной физики, Саров, Россия
}

Предложены структура и принципы реализации фотонного компьютера. В основе его

функционирования - эффекты взаимодействия когерентных систем световых волн, порождаемых лазерным источником. Получены оценки значений производительности, потребляемой энергии, физических размеров; эти оценки показывают возможные преимущества фотонного компьютера по сравнению с электронным компьютером.

\section{ВВЕДЕНИЕ}

Для решения постоянно возникающих актуальных задач требуются вычислительные машины с максимальной производительностью. Она измеряется количеством операций, выполняемых в единицу времени.

Современные вычислительные машины содержат квадриллионы электронных транзисторов размером не более 14 нм, выполняют $-10^{17}$ оп/с, потребляют десятки МВт, занимают тысячи $\mathrm{M}^{2}$.

Дальнейшее уменьшение размеров транзисторов для наращивания производительности приводит к тому, что взаимодействие между ними будет сопровождаться квантовыми эффектами. Вычислительные машины на основе таких эффектов называются квантовыми компьютерами. Они исследуются последние 30 лет, перспективы их реализации пока неопределенны [1].

Поэтому актуальна предлагаемая ниже вычислительная машина, в основе функционирования которой - эффекты взаимодействия когерентных систем световых волн, порождаемых лазерным излучением [2]. Носителями излучения являются фотоны, отсюда название - фотонный компьютер.

Фотонный компьютер, в отличие от аналогов [3, 4], оперирует только световым представлением информации. Это позволяет получить, как будет показано, значения производительности и энергоэффективности лучше достигаемых применением электронных технологий. Предложенная

\section{PHOTONIC COMPUTER:}

\author{
STRUCTURE AND
}

ALGORITHMS.

ESTIMATIONS

OF PARAMETERS

\author{
S.A.Stepanenko, Doctor of Physical and Mathematical \\ Sciences, ssa@vniief.ru; Russian Federal Nuclear \\ Center-All-Russian Research Institute of \\ Experimental Physics, Sarov, Russia
}

The structure and principles of the photon computer implementation are proposed. The effects of interaction of coherent systems of light waves generated by a laser source underlie its functioning. The estimates of the values of productivity, energy consumption, physical dimensions were obtained; these estimates show the possible advantages of a photonic computer in comparison with the electronic one.

\section{INTRODUCTION}

To solve constantly emerging problems, computational machines with maximum performance are required. It is measured by the number of operations performed per time unit.

Modern computers contain quadrillions of electronic transistors measuring no more than $14 \mathrm{~nm}$, perform $\sim 10^{17} \mathrm{op} / \mathrm{s}$, consume dozens of $\mathrm{MW}$, occupy thousands of $\mathrm{m}^{2}$.

A further reduction in the size of the transistors for increasing the capacity leads to the fact that the interaction between them will be accompanied by quantum effects. Computers based on such effects are called quantum computers. They have been studied for the past 30 years, the prospects for their implementation are still uncertain [1].

Therefore, the proposed below is a computer that is based on the interaction effects of coherent systems of light waves generated by laser radiation [2]. The carriers of radiation are photons; hence its name is photonic computer.

The photon computer, unlike the analogues [3, 4], operates only with the light representation of information. This allows to obtain, as will be shown, the values of productivity and energy efficiency better than those achieved using electronic 
статья является расширенным вариантом публикации [5].

\section{АЛГОРИТМ ФУНКЦИОНИРОВАНИЯ И СТРУКТУРА ФОТОННОГО КОМПЬЮТЕРА}

Записанная на языке высокого уровня программа транслируется электронной вычислительной машиной (ЭВМ) в электронную форму программы фотонного компьютера, которая затем преобразуется в световую форму и выполняется фотонным процессором. По окончании вычислений результат преобразуется устройством сопряжения в электронную форму и поступает в эВМ.

Структура фотонного компьютера представлена на рис.1. Выполнение вычислительного процесса начинается пусковым воздействием устройства 1 , передаваемым по каналу 2 в источник 3 лазерного излучения. Генерируемое источником 3 излучение по оптическому каналу 4 поступает в устройство 5 ввода/вывода, где делится на световые лучи, количество которых равно количеству бит (разрядов), одновременно вводимых по оптическим каналам 6 в процессорные элементы (ПЭ) 7, объединенные каналами 8 в фотонный процессор 9. Далее technologies. This article is an expanded version of the publication [5].

\section{ALGORITHM OF FUNCTIONING AND STRUCTURE OF PHOTONIC COMPUTER} The program recorded in a high-level language is translated by an electronic computer into an electronic form of a photonic computer program, which is then converted into a light form and executed by a photonic processor. At the end of the calculation, the result is transformed by the coupling device into an electronic form and enters the computer.

The structure of the photonic computer is shown in Fig. 1. The execution of the computational process begins with the starting action of the device 1, transmitted via channel 2 to the laser source 3 . The radiation emitted by the source 3 passes through the optical channel 4 to the input/output device 5 , where it is separated into light beams, the number of which is equal to the number of bits simultaneously input through the optical channels 6 into the processing elements (PE) 7, to the photonic processor 9. Further, as a result of the interaction of these beams in the device 5 with the electronic representation of the information
Puc.1. Структура фотонного компьютера Fig.1. Structure of the photonic computer

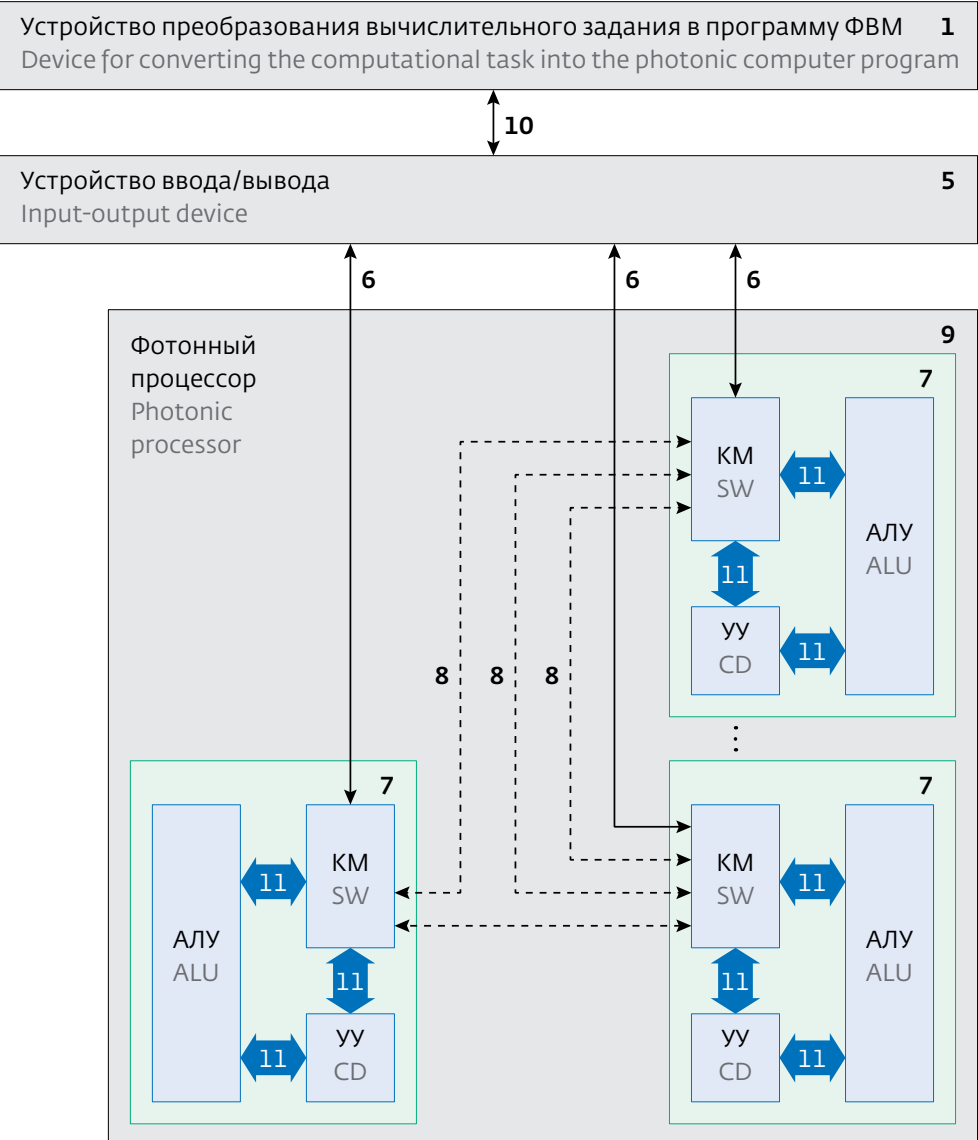


в результате взаимодействия этих лучей в устройстве 5 с электронным представлением исходной информации, вводимым по электронному каналу 10 из устройства 1 (в качестве которого можно применять ЭВМ), получается световая форма программы, поступающая по каналам 6 на выполнение в Пэ 7. Они содержат арифметико-логические устройства (АЛУ), коммутаторы (КМ) и устройства управления (УУ), объединенные оптическими каналами 11. Вычислительный процесс является последовательностью взаимодействий световых лучей в пассивных оптических логических элементах (ОЛЭ) $[6,7,8]$, из которых реализованы ПЭ 7. Функции ОЛЭ идентичны функциям электронных логических элементов [9]. Это позволяет задействовать в фотонном компьютере архитектурные реализации АЛУ, КМ и Уу, известные из электронной вычислительной техники; для синхронизации возможно использование оптических линий задержки.

Процессорные элементы в фотонном процессоре соединены каналами 8 в мультипроцессорную среду, имеющую любую известную топологию, например 3D-тор, ГП-гиперкуб и др. [10].

Общее количество выполняемых операций определяется либо бюджетом мощности [11], либо длиной когерентности [12].

После исчерпания бюджета мощности осуществляется регенерация информации. После достижения длины когерентности информация возвращается по каналам 6 в устройство 5, где преобразуется в электронную форму и затем вновь в световую когерентную форму, передаваемую в ПЭ.

\section{ПРИНЦИПЫ ВЫПОЛНЕНИЯ ВЫЧИСЛЕНИЙ}

Информация в световой форме постоянно перемещается в пространстве. Чтобы исключить ее задержки и потери мощности, необходимо:

- выполнять операции по готовности операндов без обращения в память согласно дисциплине управления от потока данных (data flow) [9];

- обрабатывать информацию по бесконфликтным маршрутам [10], задействуя в определенный, заранее известный интервал времени только свободные процессорные элементы и каналы.

Вычисляемое выражение представляется польской инверсной записью [9], на основе которой строится ярусно-параллельная форма (ЯПФ) алгоритма [13]; вершины одного яруса ЯПФ соответствуют командам, выполняемым независимо (параллельно) в течение одного и того же интервала $t$.

Из ЯПФ алгоритма получается процессорный граф. Его вершины соответствуют ПЭ, выполняю щим операции в интервалы времени t. Они сое- input via the electronic channel 10 from the device 1 (which can be used as a computer), a light form of the program is obtained, coming via channels 6 for processing into PE7. They contain arithmetic logic units (ALU), switches (SW), and control devices (CD), combined by optical channels 11. The computing process is a sequence of light beam interactions in passive optical logical elements (OLE) $[6,7,8]$, of which PE7 is implemented. The OLE functions are identical to the functions of electronic logic units [9]. This allows you to use architectural implementations of ALU, SW and CD in the photonic computer, known from electronic computer technology; the use of optical delay lines is possible for synchronization.

The processor elements in the photonic processor are connected by channels 8 to a multiprocessor environment having any known topology, for example, a 3D-torus, a $\mathrm{G}^{\mathrm{n}}$-hypercube, etc. [10].

The total number of operations performed is determined either by a power budget [11] or by a coherence length [12].

After the exhaustion of the power budget, the information is regenerated. After reaching the coherence length, the information is returned through the channels 6 to the device 5, where it is converted into an electronic form and then again into a light coherent form transmitted to the PE.

\section{PRINCIPLES OF COMPUTATION}

The information in the light form constantly moves in space. To exclude its delays and power losses, it is necessary:

- to perform operations for the readiness of operands without access to memory according to the control discipline from the data flow [9];

- to process information on conflict-free routes [10], using only free processor elements and channels at a certain, known time interval.

The computed expression is represented by the reverse polish notation [9], on the basis of which the multilevel structure (MLS) of the algorithm is constructed [13]; the vertices of one level of the MLS correspond to the commands performed independently (in parallel) during the same interval t.

A processor graph is obtained from the algorithm MLS. Its vertices correspond to a PE executing operations at time intervals $t$. They are connected by edges belonging to non-conflicting routes from channels 8. Through these channels, PEs exchange their identifiers, i.e. operation codes, operands and synchronizing symbols, which are denoted by $\varnothing$. To perform the operations, PEs that are free in interval t from other tasks are assigned; these PEs are 
динены ребрами, принадлежащими бесконфликтным маршрутам из каналов 8. По этим каналам Пэ обмениваются идентификаторами - кодами операций, операндами и синхронизирующими символами, которые обозначаются Ø. Для выполнения операций назначаются ПЭ, свободные в интервал $\mathrm{t}$ от других заданий; эти ПЭ определяются при подготовке программы в устройстве 1 на основе количества ПЭ, топологии их соединения, принадлежности к бесконфликтным маршрутам.

Программа получается из процессорного графа заменой вершин командами фотонного компьютера.

В процессе вычислений каждый идентификатор сопровождается текущим значением $\mathrm{t}=0,1, \ldots, \mathrm{m}$, где $\mathrm{m}$ - глубина ЯПФ алгоритма [13]. Значение t увеличивается на единицу при каждом "прохождении" ПЭ.

Процессорные элементы, не задействованные в выполнении команд программы, в каждом интервале принимают и передают символ Ø и значения $\mathrm{t}$ (увеличивая t на единицу).

Процессорный элемент выполняет операцию лишь тогда, когда по всем его каналам 8 получена информация с одинаковым, очередным значением t.

\section{ПРИМЕР ВЫЧИСЛИТЕЛЬНОГО ПРОЦЕССА}

Построим процессорный граф для вычисления значения выражения $A=a+(b+c) \cdot d$ фотонным компьютером, ПЭ которого объединены в $\Gamma^{3}-$ трехмерный гиперкуб [10], показанный на рис.2. Номера обозначений на рис. 1 и на рис. 2 совпадают.

Каждая вершина $\Gamma^{3}$ означает процессорный элемент, которому соответствует вектор $\tilde{\sigma}=\left(\sigma_{3}, \sigma_{2}, \sigma_{1}\right)$, где $\sigma_{\mathrm{i}} \in\{0,1\}, \mathrm{i}=1,2,3$.

Ребра, соединяющие вершины $\Gamma^{3}$, соответствуют каналам 8, они помечены $8_{1}, 8_{2}, 8_{3}$.

Кроме того, ПЭ соединены с устройством 5 каналами $6_{1}, 6_{2}, 6_{3}$, внешними для $\Gamma^{3}$. На рис.2 каналы $6_{1}, 6_{2}, 6_{3}$ показаны только для ПЭ в вершине $(0,0,1)$.

Для $\Gamma^{3}$ и длины маршрута три имеем [10] четыре бесконфликтных множества ((000),(111)), ((001),(110)), $((010),(101))$ и ((100),(011)). Их вершины и соединяющие эти вершины бесконфликтные маршруты помечены на рис.2 цветами - черным, зеленым, красным и синим соответственно. Направления передачи показаны стрелками.

В табл.1 и 2 для элементов $(0,0,0)$ и $(0,0,1)$ приведены векторы б, соответствующие процессорным элементам, от которых по каналам $8_{1}, 8_{2}, 8_{3}$ в интервалы $\mathrm{t}=0,1, \ldots, 6$ по бесконфликтным маршрутам поступает информация. determined when preparing the program in device 1 based on the number of PE, the topology of their connection, belonging to the conflict-free routes.

The program is obtained from the processor graph by replacing the vertices with photonic computer commands.

During the calculation each identifier is accompanied by the current value $\mathrm{t}=0,1, \ldots, \mathrm{m}$, where $\mathrm{m}$ is the depth of the algorithm MLS [13]. The value of $\mathrm{t}$ is incremented by one for each "passing" of the PE.

The processor elements that are not used in the execution of program instructions in each interval receive and transmit the symbol $\varnothing$ and the value of $t$ (increasing $\mathrm{t}$ by one).

The processor element performs the operation only when the data with the same successive value of $t$ is received through all its channels.

\section{EXAMPLE OF THE COMPUTING PROCESS}

Let's plot a processor graph to calculate the value of the expression $A=a+(b+c) \times d$ by a photonic computer, the PEs of which is combined in $\mathrm{C}^{3}-$ three-dimensional hypercube [10] as shown in Fig. 2. The numbers of the notations in Fig. 1 and Fig. 2 coincide.

Each vertex of $\mathrm{C}^{3}$ means the processor element to which the vector corresponds $\tilde{\sigma}=\left(\sigma_{3}, \sigma_{2}, \sigma_{1}\right)$, where, $\sigma_{\mathrm{i}}=1,2,3$.

The edges connecting the vertices of $\mathrm{G}^{3}$ correspond to the channels 8 , they are labeled $8_{1}, 8_{2}, 8_{3}$.

Furthermore, PEs are connected to the device 5 by channels $\sigma_{1}, G_{2}, G_{3}$, external for $G^{3}$. Fig. 2 shows channels $6_{1}, 6_{2}, \sigma_{3}$ only for PE at the vertex $(0,0,1)$.

For $\mathrm{C}^{3}$ and the route length 3 , we have [10] four conflict-free sets ((000), (111)), (001), (110)), ((010), (101)) and ((100), (011)). Their vertices and the conflict-free routes connecting these peaks are marked in Fig. 2 by black, green, red and blue, respectively. The directions of the transfer are shown by arrows.

Tables 1 and 2 for the elements $(0,0,0)$ and $(0,0,1)$ give vectors ơcorresponding to the processor elements, from which through the channels $8_{1}, 8_{2}, 8_{3}$ to the intervals $t=0,1, \ldots, 6$ by conflict-free routes receive information.

The algorithm MLS for the expression $A=a+(b+c) \times d$ in the record $A a b c+d x+:=$ is shown in Fig. 3, the processor graph is shown in Fig. It consists of the vertices corresponding to the processor elements $(\sigma 3, \sigma 2, \sigma 1)$, in time intervals $\mathrm{t}$ and denoted $(\sigma 3, \sigma 2$, б1) t. The vertices are connected by edges from the channels 8 belonging to the conflict-free routes. 
ЯПФ алгоритма для выражения $\mathrm{A}=\mathrm{a}+(\mathrm{b}+\mathrm{c}) \cdot \mathrm{d}$ в записи $A a b c+d x+:=$ представлена на рис.3, процессорный граф - на рис.4. Он состоит из вершин, соответствующих процессорным элементам $\left(\sigma_{3}, \sigma_{2}, \sigma_{1}\right)$ в интервалы времени $t$ и обозначаемых $\left(\sigma_{3}, \sigma_{2}, \sigma_{1}\right)$ t. Вершины соединены ребрами из каналов 8 , принадлежащими бесконфликтным маршрутам.

Идентификаторы загружаются соответственно в вершины $(0,0,1)_{0}$ - идентификатор операции $\{x\}$ и значения "b" и "d", в $(0,1,0)_{0}$ - значения "A", "a" и "c", в $(1,0,0)_{0}$ - идентификаторы операции $\{+\},\{+\}$ и $\{:=\}$. Перечисленные символы поступают из устройства 5 по каналам 6, как показано на рис.4. В остальные элементы поступают символы Ø.

Показанный, в частности, на рис.4 маршрут идентификатора А в интервалы $\mathrm{t}=0,1,2,3,4$ состоит из вершин $(0,1,0)_{0},(1,1,0)_{1},(0,1,0)_{2},(0,1,1)_{3},(0,0,1)_{4}$. Маршруты символов $\varnothing$ показаны частично пун ${ }^{-}$ ктирными линиями.

Заменяя вершины графа командами, получаем программу для фотонного компьютера. Программа состоит из команд, предписывающих действия, выполняемые в каждый интервал $\mathrm{t}$ каждым ПЭ по каждому каналу.

Различаем три фазы выполнения команды:

- фаза $\varphi=1$; прием информации из каналов в ПЭ;

- фаза $\varphi=2$; выполнение ПЭ действий, предписываемых кодом операции;

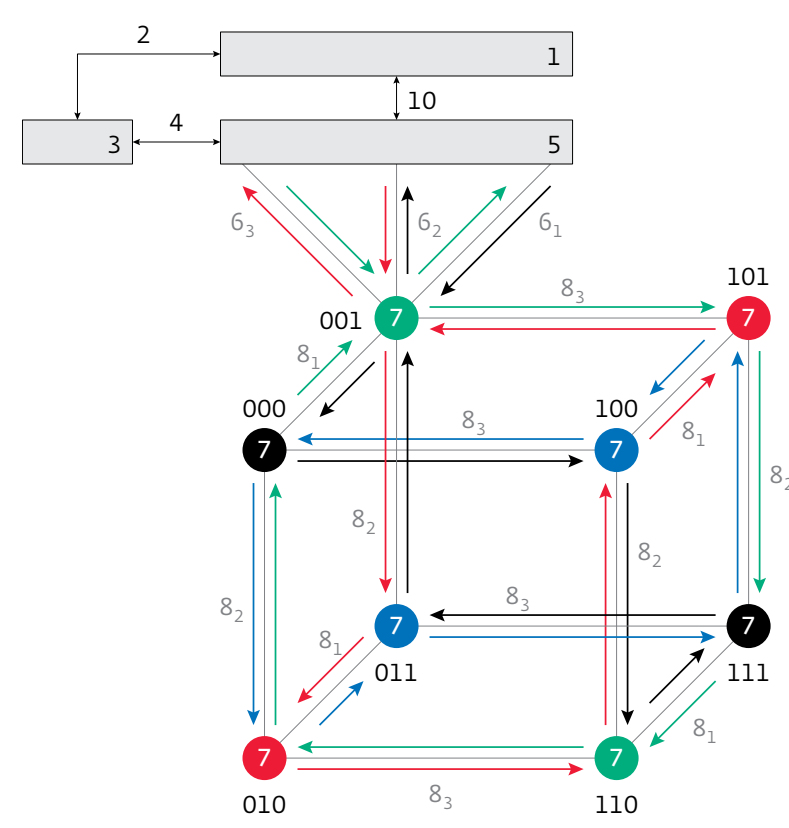

Puc.2. Структура фотонного компьютера c monологией $\Gamma^{3}$

Fig.2. Structure of the photonic computer with the $\mathrm{G}^{3}$ topology
Таблица 1. Поступление информации в ПЭ (000)

Table 1. Information input to the PE (000)

\begin{tabular}{|c|c|c|c|c|}
\hline & $8_{1}$ & $8_{2}$ & $8_{3}$ \\
\hline 0 & 001 & 010 & 100 \\
\hline 1 & 000 & 000 & 000 \\
\hline 2 & 001 & 010 & 100 \\
\hline 3 & 011 & 110 & 101 \\
\hline 4 & 111 & 111 & 111 \\
\hline 5 & 110 & 101 & 011 \\
\hline 6 & 100 & 001 & 010 \\
\hline
\end{tabular}

Таблица 2. Поступление информации в ПЭ (001) Table 2. Information input to the PE (001)

\begin{tabular}{|c|c|c|c|}
\hline$t$ & $8_{1}$ & $8_{2}$ & $8_{3}$ \\
\hline 0 & 000 & 011 & 101 \\
\hline 1 & 001 & 001 & 001 \\
\hline 2 & 000 & 011 & 101 \\
\hline 3 & 010 & 111 & 100 \\
\hline 4 & 110 & 110 & 110 \\
\hline 5 & 111 & 100 & 010 \\
\hline 6 & 101 & 000 & 011 \\
\hline
\end{tabular}

The identifiers are loaded respectively into the vertices $(0,0,1)_{0}$ - the identifier of the operation $\{x\}$ and the values of "b" and "d", in $(0,1,0)_{0}$ - the values of "A", "a" and "c", in $(1,0,0)_{0}$ - the identifiers of the operation $\{+\},\{+\}$ and $\{:=\}$. The symbols listed follow from device 5 through channels 6 as shown in Fig. 4. The remaining elements are followed by the symbols $\varnothing$.

This is shown, in particular, in Fig. 4 the route of the identifier $\mathrm{A}$ in the intervals $\mathrm{t}=0,1,2,3,4$ consists of the vertices $(0,1,0)_{0},(1,1,0)_{1},(0,1,0)_{2},(0,1.1)_{3},(0.0 .1)_{4}$. The characters routes are shown in partial, with dotted lines.

By replacing the vertices of the graph with commands, we obtain a program for a photonic computer. The program consists of the commands that prescribe the actions to be performed at each interval $t$ by each $\mathrm{PE}$, for each channel. 
- фаза $\varphi=3$; передачи информации из ПЭ приемникам в других ПЭ.

В таблице 3 приведена программа фотонного процессора с топологией $\Gamma^{3}$, полученная из процессорного графа, представленного на рис.4. В каждом столбце $\left(\sigma_{3}, \sigma_{2}, \sigma_{1}\right)$ при $\varphi=1$ запись $\frac{x}{z}$ означает, что в интервал $\mathrm{t}=\mathrm{z}$ идентификатор $\mathrm{x}$ принимается по каналу $8_{\mathrm{i}}$ ПЭ $\left(\sigma_{3}, \sigma_{2}, \sigma_{1}\right) ; \varphi=2$ указывает на выполнение операции данным ПЭ в течение интервала $\mathrm{t}=\mathrm{z}$ (прочерк означает отсутствие операции); при $\varphi=3$ запись $\frac{x}{Z}$ означает, что в интервал z идентификатор x передается по каналу $8_{\mathrm{i}}$ Пэ $\left(\sigma_{3}, \sigma_{2}, \sigma_{1}\right)$; цвет черты в записи $\frac{\mathrm{x}}{\mathrm{z}}$ совпадает с цветом маршрута, по которому принимается или передается информация.

Подробности трансляции программ, записан ${ }^{-}$ ных на языках высокого уровня, и особенности получения "машинного" представления этих программ здесь несущественны. Могут быть использованы все известные средства, позволяющие оптимизировать трансляцию и порождаемый в результате ее выполнения машинный код.

\section{ОСОБЕННОСТИ РЕАЛИЗАЦИИ ФОТОННОГО ПРОЦЕССОРА \\ Топологии связей фотонного процессора}

Фотонный процессор представляет собой мультипроцессорную среду, состоящую из ПЭ, соединенных каналами связи.

Можно задействовать любую известную [10] топологию связей - 1D тор, 2D тор, 3D тор, $\mathrm{H}^{\mathrm{m}}$, $\Gamma^{\mathrm{n}}$-гиперкуб, N-полный матричный коммутатор, S-звезда, F-полносвязное дерево, реализованное из q-портовых коммутаторов. Критериями выбора являются указанные в табл.4 значения величины $\mathrm{D}_{\mathrm{k}}$ - количество маршрутов между двумя ПЭ, находящимися на расстоянии $\mathrm{k}$ (измеряемым минимальным количеством ребер между ними), а также указанные в табл. 5 значения С и С-мощности и количества бесконфликтных множеств, которые оцениваются относительно диаметра среды - минимального значения $\mathrm{k}$, достаточного для соединения любых двух элементов среды, содержащей $\omega$ ПЭ. Значения $\mathrm{D}_{\mathrm{k}}$, C и $\mathrm{G}$ получены в [10]. Они определяют коммуникационные возможности среды и, следовательно, параметры процессорных графов и программ.

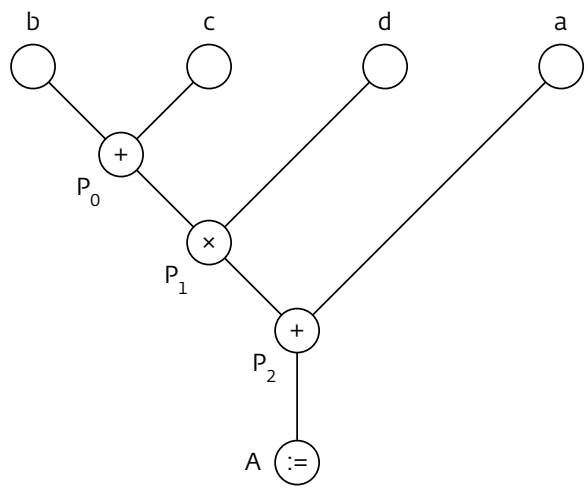

Puс.3. ЯПФ алгоритма для вычисления значения $A=a+(b+c) \times d$ в зanucu $A a b c+d x+:=$ Fig. 3. MLS of the algorithm for calculating the value of $A=a+(b+c) \times d$ in the entry $A a b c+d x+:=$

We distinguish three phases of the command:

- phase $\varphi=1$; reception of information from channels to PE;

- phase $\varphi=2$; execution of PE actions prescribed by the operation code;

- phase $\varphi=3$; transfer of information from PE to receivers in other PEs.

Table 3 shows the photonic processor program with the $\mathrm{G}^{3}$ topology, obtained from the processor graph shown in Fig. In each column $(\sigma 3, \sigma 2, \sigma 1)$ for $\varphi=1$, the notation $\frac{x}{Z}$ means that the identifier $x$ is taken over the channel $8_{\mathrm{i}}$ PE in the interval $\mathrm{t}=\mathrm{z}(\sigma 3, \sigma 2, \sigma 1) ; \varphi=2$ indicates that the operation is performed by the $\mathrm{PE}$ data during the interval $t=z$, the dash indicates no operation; for $\varphi=3$, the record $\frac{x}{Z}$ means that in the interval $z$ the identifier $x$ is transmitted via the $8_{i} P E$ channel $(\sigma 3, \sigma 2, \sigma 1)$; the color of the line in the record $\frac{X}{Z}$ is the same as the color of the route on which the information is received or transmitted.

The details of the translation of programs written in high-level languages and the features of obtaining the "machine" representation of these programs are inessential here. All known means can be used to optimize the translation and the generated machine code. 
Таблица 3.Программа фотонного процессора вычисления выражения $\mathrm{A}=\mathrm{a}+(\mathrm{b}+\mathrm{c}) \cdot \mathrm{d}$ в записи $\mathrm{Aab} \mathrm{b}+\mathrm{d} \mathrm{x}+\mathrm{:}=$ Table 3. The program of the photon processor evaluating the expression $A=a+(b+c) \times d$ in $A a b c+d x+:=$

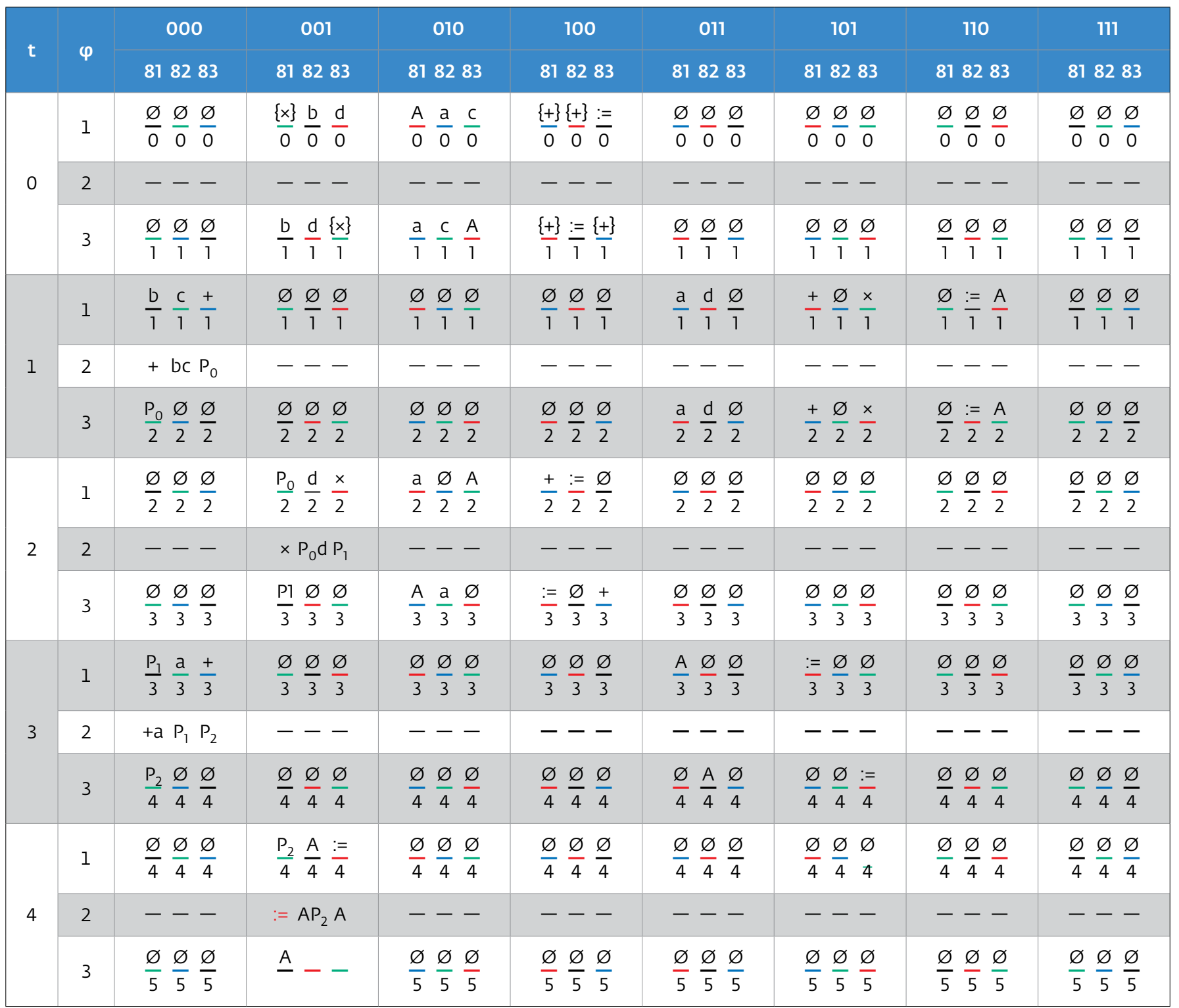

Самой "примитивной" является среда 1D тор. Наилучшие значения C и С имеют наиболее сложные в аппаратной реализации среды $\mathrm{N}$ и S. Приемлемые на практике значения аппаратной сложности имеют среды с топологией $\mathrm{F}$ и $\Gamma^{\mathrm{n}}$. Эти среды характеризуются близкими значениями $\mathrm{D}_{\mathrm{k}}, \mathrm{C}$ и $\mathrm{G}$.

Среда $\Gamma^{\mathrm{n}}$ имеет удобный аппарат построения бесконфликтных маршрутов и формальное описание булевыми функциями, для нее предложены средства топологического резервирования, позволяющие автоматически замещать отказавшие ПЭ с полным сохранением топологии среды и вычислительного процесса [10].

\section{FEATURES OF PHOTONIC PROCESSOR IMPLEMENTATION Photonic processor communications topologies}

The photonic processor is a multiprocessor environment consisting of PEs connected by communication channels.

It is possible to use any known [10] topology of the connections $-1 \mathrm{D}$ torus, $2 \mathrm{D}$ torus, 3D torus, $\mathrm{N}^{\mathrm{m}}$, $\mathrm{G}^{\mathrm{n}}$-hypercube, N-full matrix switch, S-star, F-fully connected tree realized from q-port switches. The criteria for selection are the values of $\mathrm{Dk}$ - the number of routes between two PEs located at a distance $k$ (measured by the minimum number of edges between them) indicated in Table 4, as well as the values 


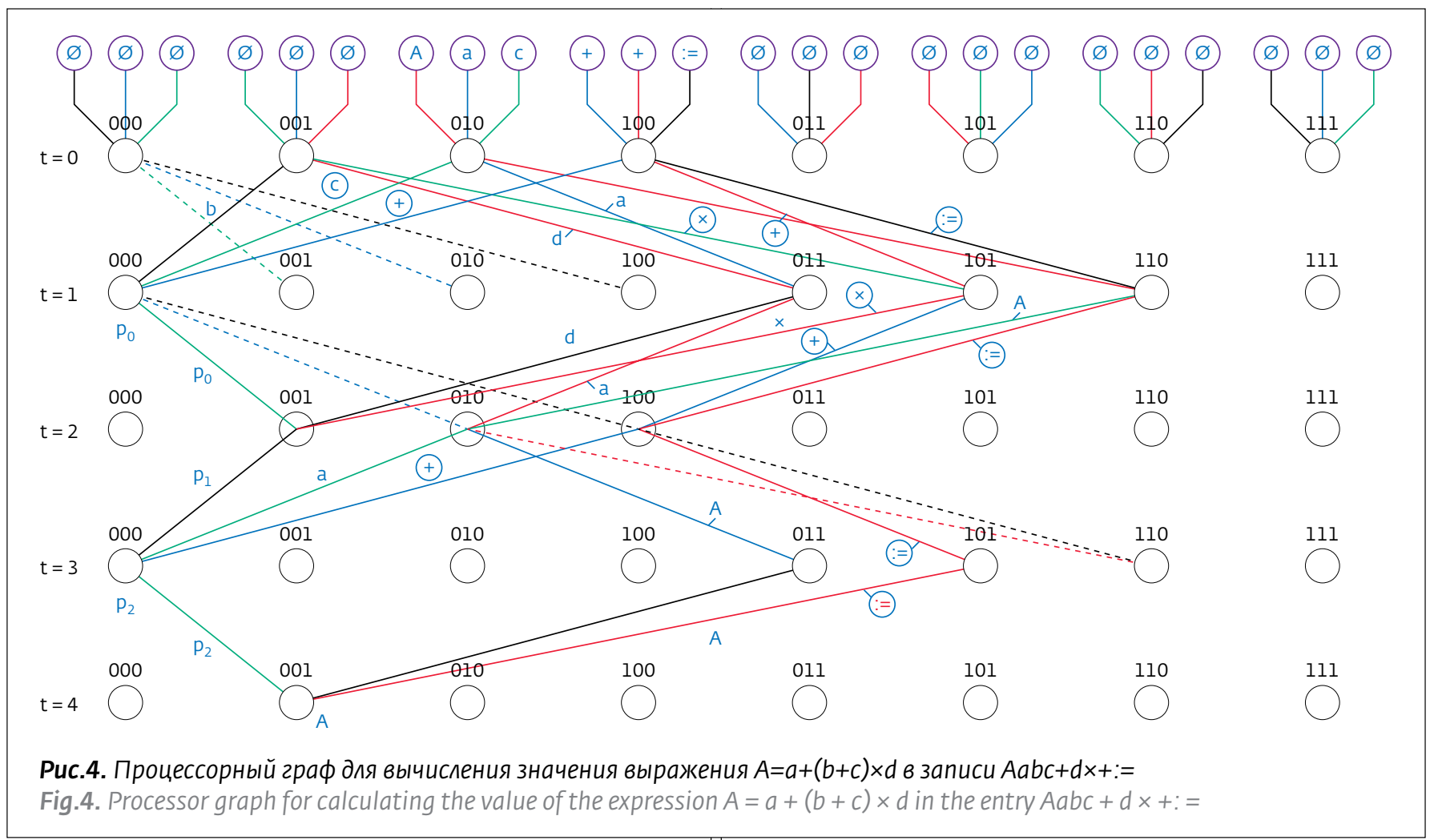

\section{Взаимодействие с внешней средой}

Обмен фотонного процессора с внешней средой должен занимать как можно меньше времени. Это достигается, если каждому ПЭ фотонного процессора предоставить доступ к внешней среде, например, назначить электронный процессор, который реализует функции хранения и обмена информацией.

Электронные процессоры, соответствующие элементам фотонного процессора, можно объединить каналами связи в мультипроцессорную среду, в частности имеющую ту же топологию, что и фотонный процессор. Это позволяет задействовать одинаковое описание электронной и фотонной компонент фотонного компьютера.

\section{Элементная база фотонного процессора}

Элементная база - функционально полный набор ОЛЭ, позволяющий выполнять любые арифметические и логические операции. Таким набором (неединственным) являются элементы, реализующие три логические функции "И", "ИЛИ", "НЕ" [9].

Эти элементы могут быть реализованы применением различных эффектов, например интерференционных [6], нелинейных [7] и др. [8]. Они пассивны, не требуют дополнительной энергии накачки. Все операции осуществляются лишь со световой формой представления информации. Длительность выпол- of $C$ and $C$ in Table 5 - the power and the number of conflict-free sets that are estimated relative to environment diameter - the minimum value of $k$, sufficient to connect any two elements of the environment containing $\omega$ PEs. The values of $D_{k}$, $C$, and $\mathrm{C}$ were obtained in [10]. They determine the communication capabilities of the environment and, consequently, the parameters of the processor graphs and programs.

The "primitive" environment is $1 \mathrm{D}$ torus. The best values of $\mathrm{C}$ and $\mathrm{G}$ have the most complex $\mathrm{N}$ and $\mathrm{S}$ environments in the hardware implementation of the environment. The environments with topologies $\mathrm{F}$ and $\mathrm{G}^{\mathrm{n}}$ are acceptable in practice for hardware complexity. These environments are characterized by close values of $D_{k}, C$, and $\mathrm{C}$.

The environment of $\mathrm{G}^{\mathrm{n}}$ has a convenient arrangement for constructing conflict-free routes and a formal description of Boolean functions, it provides for topological backup facilities that automatically replace failed PE with full maintenance of the environment topology and computational process [10].

\section{Interaction with the environment}

The photonic processor's exchange with the external environment should take as little time as possible. This is achieved if each PE photonic processor has access to 
нения операции определяется длительностью распространения света в ОЛЭ.

\section{ОЦЕНКИ ПАРАМЕТРОВ}

Полагаем, что в фотонном компьютере на рис.2 задействован источник лазерного излучения мощностью $\mathrm{P}_{\Sigma}=100$ Вт и длиной волны $\lambda=1530$ нм; мощность излучения, поступающего во входные волноводы ПЭ, составляет $\mathrm{P}_{1}=1$ мВт, минималь ная оптическая мощность на входе ОЛЭ, основанном на эффекте интерференции [6], составляет 100 нВт [11].

Бюджет оптической мощности ПЭ составит $\mathrm{b} \cdot 40$ дБ, где $\mathrm{b}=\mathrm{P}_{\Sigma} / 8 \cdot \mathrm{P}_{1} \approx 10^{4}$ шт. - количество входных олЭ в каждом ПЭ.

Эффективность ввода излучения в волновод принимаем 90\% [14]. Полагаем, что потери в ОЛЭ и в волноводах совпадают и равны $\Delta=0,1-1,0$ дБ/см [14]. Суммарная длина волноводов ОЛЭ одного ПЭ не превышает $\mathrm{L}=\mathrm{b} \cdot(0,35-3,5) \mathrm{M}$.

Полагая длину волновода ОЛЭ $\mathrm{D}=50 \lambda=75 \cdot 10^{-6} \mathrm{M}$, диаметр входного волновода ОЛЭ из [6] $\mathrm{h}=7,5 \cdot 10^{-6} \mathrm{M}$, находим [12] расстояние между входами ОЛэ $\mathrm{l}=7,5 \cdot 10^{-6} \mathrm{M}$.

В одном Пэ можно разместить $\rho=\mathrm{L} / \mathrm{D}=4,7 \cdot 10^{7}-4,7 \cdot 10^{8}$ шт. ОЛЭ.

Необходимое количество ОЛЭ в $\mathrm{n}=64$ разрядном умножителе согласно [9] не превышает $\left(23 n^{2}+5 n-58\right) \approx 10^{5}$ шт.

Аппаратно Уу не сложнее АЛУ [9], следовательно, $\rho=\mathrm{L} / \mathrm{D}=4,7 \cdot 10^{7}-4,7 \cdot 10^{8}$ штук ОЛЭ достаточно для реализации ПЭ, содержащего 230-2300 АЛУ. Известно [9], длительность выполнения операции умножения n-разрядных чисел составляет $\mathrm{t}^{*} \approx 41,5 \cdot \mathrm{n} \cdot \tau$, где $\tau$ - длительность срабатывания элемента, здесь $\tau=\mathrm{D} / \mathrm{v}$ - длительность задержки в одном ОЛЭ, $\mathrm{v}=2 \cdot 10^{8} \mathrm{~m} / \mathrm{c}-$ скорость света в волноводе. Для $\mathrm{n}=64$ производительность АЛУ составит $\pi=10^{9}$ оп/с, производительность ПЭ $\pi^{*}=2,3 \cdot 10^{11-2,3 \cdot 10^{12}}$ оп/с, производительность всего фотонного компьютера

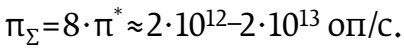

Применяя архитектурные средства для оптимизации структуры АЛу и ПЭ [9], можно получать результат операции каждый интервал $\tau$ и достигнуть пиковой производительности фотонного компьютера $\tilde{\pi}_{\Sigma}$. Для $\lambda=1530$ нм и $\mathrm{D}=50 \lambda$ имеем $\tilde{\pi}_{\Sigma} \approx 5 \cdot 10^{15}-5 \cdot 10^{16}$ оп/с.

Значения $\pi_{\Sigma}$ и $\tilde{\pi}_{\Sigma}$ для различных $\lambda$ при $\mathrm{P}_{\Sigma}=100 \mathrm{BT}$ сведены в табл. 6.

Для ОЛЭ из [6] уменьшение значения D в z раз (например в результате уменьшения $\lambda$ ) увеличивает производительность процессора в $z^{2}$ раз (при неизменном бюджете мощности и равных потерях).
Таблица 4. Количество маршрутов длины k

Table 4. Number of length $k$ routes

\begin{tabular}{|l|c|c|c|c|c|c|}
\hline Среда & 1D & 2D & 3D & $\Gamma^{\mathrm{n}}$ & $\mathrm{N}$ & $\mathrm{F}$ \\
\hline $\mathrm{D}_{\mathrm{k}}$ & 2 & $2 \cdot 2^{\frac{\mathrm{k}}{2}}$ & $4 \mathrm{k}^{2} \cdot 2^{\frac{\mathrm{k}}{2}}$ & $\mathrm{k} !$ & 1 & $\left(\frac{\mathrm{q}}{2}\right)^{\mathrm{k}-1}$ \\
\hline
\end{tabular}

the external environment, for example, is assigned with an electronic processor that implements the functions of storing and exchanging information.

The electronic processors corresponding to the elements of the photonic processor can be combined by communication channels into a multiprocessor environment, in particular, having the same topology as the photonic processor. This allows you to use the same description of the electronic and photonic components of the photonic computer.

\section{Element base of the photonic processor}

Element base is a functionally complete set of OLE that allows performing any arithmetic and logical operations. Such a set (non-unique) is the elements realizing the three logical functions "AND", "OR", "NOT" [9].

These elements can be realized by applying various effects, for example, interference [6], nonlinear [7], and others [8]. They are passive, they do not require additional pumping energy. All operations are carried out only with the light-form presentation of information. The duration of the operation is determined by the duration of light propagation in the OLE.

\section{ESTIMATIONS OF THE PARAMETERS}

We assume that the photonic computer shown in Fig. 2 involves a laser radiation source with a power $\mathrm{P}_{\Sigma}=100 \mathrm{~W}$ and a wavelength $\lambda=1530 \mathrm{~nm}$; the power of radiation entering the input waveguides of the $\mathrm{PE}$ is $\mathrm{P}_{1}=1 \mathrm{~mW}$, the OLE minimum optical power at the input, based on the interference effect [6], is $100 \mathrm{nW}[11]$.

The optical power budget of the PE will be $\mathrm{b} \cdot 40 \mathrm{~dB}$, where $b=\mathrm{P}_{\Sigma} / 8 \cdot \mathrm{P}_{1} \approx 10^{4}$ pcs. - the number of input OLE in each $\mathrm{PE}$.

The efficiency of the radiation input into the waveguide is assumed to be $90 \%$ [14]. We assume that the OLE and waveguides losses coincide and are equal to $\Delta=0.1-1.0 \mathrm{~dB} / \mathrm{cm}$ [14]. The total length of the OLE waveguides of one PE does not exceed $\mathrm{L}=\mathrm{b} \cdot(0.35-3.5) \mathrm{m}$.

Assuming the length of the OLE waveguide $\mathrm{D}=50 \lambda=75 \cdot 10^{-6} \mathrm{~m}$, the diameter of the OLE input 
Таблица 5. Мощности и количества бесконфликтных множеств

Table 5. Means and quantities of conflict-free sets

\begin{tabular}{|c|c|c|c|c|c|c|c|}
\hline Среда & 1D тор & 2D тор & 3D тор & $\begin{array}{c}H^{m} \\
m=2^{r-1}, r=0,1,2, \ldots\end{array}$ & $\Gamma^{\mathrm{n}}$ & $\begin{array}{l}N \\
S\end{array}$ & $\mathrm{~F}$ \\
\hline C & 2 & $2 \sqrt{\omega}$ & $\omega^{\frac{2}{3}}$ & $\frac{\omega}{2}$ & $\frac{\omega}{2}$ & $\frac{\omega}{2}$ & $\frac{\omega}{2}$ \\
\hline G & $\frac{\omega^{2}}{2}$ & $2 \sqrt{\omega} \cdot 2^{\sqrt{\omega}}$ & $\omega^{\frac{2}{3}} \cdot 2^{\omega^{\frac{2}{3}}}$ & $\left(\left(_{\log \omega}^{\log \omega}\right) \frac{\log \omega}{2} \cdot 2^{\frac{\omega}{\log \omega}}\right.$ & $\left(\begin{array}{l}n \\
m\end{array}\right) \cdot G\left(H^{m}\right)$ & $2^{\omega-1}$ & $\frac{\omega}{2 q^{2}} 2^{9} \cdot 2^{\frac{\omega}{2 k}}$ \\
\hline
\end{tabular}

Оценки производительности $\tilde{\pi}_{\Sigma}$ и энергоэффективности $\tilde{\pi}_{\Sigma} / \mathrm{P}_{\Sigma}$ рассмотренного фотонного компьютера в $10^{3-10^{4}}$ раз при $\lambda=1530 \mathrm{Hм}, \mathrm{D}=50 \lambda$ и $\Delta=0,1^{-}$ 1,0 дБ/см превосходят достигаемые современными ЭВМ [15].

Для размещения ПЭ потребуется кремниевая подложка длиной не более $\mathrm{D} \cdot 4,7 \cdot 10^{8}=352 \cdot 10^{2} \mathrm{M}$ и шириной $s \approx 100$ мкм (очевидно, $s>h$ и $s>2 \mathrm{l}$ ). Площадь ПЭ составляет $35 \cdot 10^{-1} \mathrm{M}^{2}$. При толщине подложки 100 мкм, объем восьми ПЭ составит $\mathrm{V}=0,28 \cdot 10^{-3} \mathrm{M}^{3}$. waveguide from [6] $h=7.5 \cdot 10^{-6} \mathrm{~m}$, we find [12] the distance between the OLE inputs $l=7.5 \cdot 10^{-6} \mathrm{~m}$.

One PE can house $\rho=\mathrm{L} / \mathrm{D}=4.7 \cdot 10^{7}-4.7 \cdot 10^{8} \mathrm{pcs}$. of OLE.

The required amount of OLE in the $n=64$ bit multiplier according to [9] does not exceed $\left(23 n^{2}+5 n-58\right) \approx 10^{5}$ pcs.

Hardware-wise, the CD is not more complicated than the ALU [9], therefore, $\rho=\mathrm{L} / \mathrm{D}=4.7 \cdot 10^{7}-4.7 \cdot 10^{8}$ pcs. of OLE are sufficient for implementation of $\mathrm{PE}$ containing 230-2300 ALU. It is known [9] that the duration of the operation of multiplication of n-bit 
Это приемлемый размер конструктивного элемента, позволяющий отвести 100 Вт тепла посредством обычного воздушного охлаждения.

\section{ЗАКЛЮЧЕНИЕ}

Эффективность обработки информации в световой форме достигается совместным применением в фотонном компьютере:

- пассивных оптических логических элементов;

- дисциплины вычислений по готовности операндов;

- бесконфликтных алгоритмов обработки информации процессорными элементами, соединенными в мультипроцессорную среду.

Классы задач, решаемых фотонными и электронными вычислительными машинами, совпадают.

Выполненный анализ и полученные оценки демонстрируют возможность достижения фотонным компьютером, задействующим излучение с длиной волны 1530 нм, пиковой производительности в 103$10^{4}$ раз превышающей достигаемую современными электронными вычислительными устройствами при равных энергетических затратах.

Применение технологий, обеспечивающих задействование в фотонном компьютере ультрафиолетового излучения с длиной волны 100 нм позволяет фотонному компьютеру достигнуть экзафлопсной производительности $\left(10^{18}\right.$ оп/с) на 100 Вт потребляемой мощности.

Излучения с различными длинами волн не взаимодействуют между собой. При надлежащей реализации ОЛЭ в одном фотонном компьютере могут одновременно выполняться несколько вычислительных процессов, представленных световыми волнами различной длины.

\section{ЛИТЕРАТУРА}

1. Binkley S. Quantum Computing. ASCAC DOE US. April 5, 2016 [Электронный ресурc]. Режим доступа: https://science.energy.gov/ /media/ascr/ascac//ddf/ meetings/201604/2016-0405-ascac-quantum-02.pdf.

2. Тарасов Л.В. Физика лазера. Изд. 2-е, испр. и доп.-М.. Книжный дом "ЛИБРОКОМ", 2010.

3. Белов П.А., Беспалов В.Г., Васильев В.Н., и др. Оптическиепроцессоры: достижения и новые идеи [Электронный ресурс]. Режим доступа: http://pandia. ru/77/192/21190.php.

4. Russel John. Hight-enabled Microprocessor Holds Promise for Faster Computers. February 23, 2016 [Электронный ресурс]. Режим доступа: http://nww/hpcwire. numbers is $t^{*} \approx 41.5 \cdot n \cdot \tau$, where $\tau$ is the operation time of the element, here $\tau=\mathrm{D} / v$ is the delay time in one OLE, $v=2 \cdot 10^{8} \mathrm{~m} / \mathrm{s}$ is the speed of light in the waveguide. For $\mathrm{n}=64$, the performance of the ALU is $\pi=10^{9} \mathrm{op} / \mathrm{s}$, the performance of the PE $\pi^{*}=2.3 \cdot 10^{11}-2.3 \cdot 10^{12} \mathrm{opt} / \mathrm{s}$, the performance of the entire photon computer $\pi_{\Sigma}=8 \cdot \pi^{*} \approx 2 \cdot 10^{12}-2 \cdot 10^{13} \mathrm{op} / \mathrm{s}$.

Using architectural means to optimize the structure of ALU and PE [9], it is possible to obtain the result of the operation every interval $\tau$ and to reach the peak performance of a photonic computer $\tilde{\pi}_{\Sigma}$. For $\lambda=1530 \mathrm{~nm}$ and $\mathrm{D}=50 \quad \lambda$ we have $\tilde{\pi}_{\Sigma} \approx 5 \cdot 10^{15} \mathrm{op} / \mathrm{s}-5 \cdot 10^{16} \mathrm{op} / \mathrm{s}$.

The values of $\pi_{\Sigma}$ and $\tilde{\pi}_{\Sigma}$ for different $\lambda$ when $\mathrm{P}_{\Sigma}=100 \mathrm{~W}$ are summarized in Table 6 .

For OLE from [6], a decrease in the value of $D$ by a factor of $z$ (for example, as a result of decreasing $\lambda$ ) increases the processor's performance in $z^{2}$ times (with a constant power budget and equal losses).

The estimates of productivity $\tilde{\pi}_{\Sigma}$ and energy efficiency $\tilde{\pi}_{\Sigma} / \mathrm{P}_{\Sigma}$ of the photon computer is $10^{3}-10^{4}$ times higher at $\lambda=1530 \mathrm{~nm}, \mathrm{D}=50 \lambda$ and $\Delta=0.1^{-}$ $1.0 \mathrm{~dB} / \mathrm{cm}$ than those achieved by modern computers [15].

To arrange PE, a silicon substrate with a length of no more than $\mathrm{D} \cdot 4$ is required, $7 \cdot 10^{8}=352 \cdot 10^{2} \mathrm{~m}$ and width $\mathrm{s} \approx 100 \mu \mathrm{m}$ (obviously $\mathrm{s}>\mathrm{h}$ and $\mathrm{s}>2 \mathrm{l}$ ). Area of the $P E$ is $35 \cdot 10^{-1} \mathrm{~m}^{2}$. With a substrate thickness of $100 \mu \mathrm{m}$, the volume of the eight PE will be $\mathrm{V}=0.28 \times 10^{-3} \mathrm{~m}^{3}$.

This is an acceptable size of the structural element that allows $100 \mathrm{~W}$ of heat to be drawn off by means of conventional air cooling.

\section{CONCLUSION}

The efficiency of information processing in the light form is achieved by joint application in a photonic computer of: 
com/2016/02/23/25120/

5. Степаненко С.А. Фотонная вычислительная машина. Принципы реализации. Оценки параметров. - ДокладыАкадемии наук, 2017, т. 476, № 4, с. 389-394.

6. Патент РФ 20751061 от 10.03.1997. Оптический логический элемент/

Полуэктов А.0.

7. Kumar A. Implementation of all-optical NAND logic gate and halfadder using the micro-ring resonator structures. - Optical and Quantum Electronics, October 2016.

8. Кузнецова О.В., Сперанский В.С. Решение задач обработки оптических сигналов без оптоэлектронного преобразования. -Т-Сomm, 8-2012, с.35-39.

9. Цилькер Б.Я., Орлов С.А. Организация ЭВМ и систем.-С-Пб.: Изд-ВО "ПИТЕР", 2015.

10. Степаненко С.А. Мультипроцессорные среды супер ЭВМ. Масштабирование эффективности.-М.: Физматлит, 2016.

11. Вербовецкий А.А. Основы проектирования оптоэлектронных систем связи.М.: Радио и связь, 2000

12. Яворский Б.М., ДетлафА.А., Лебедев А.К. Справочникпо физике для инженеров и студентов вүзов. - М.: ООО "Издательство Оникс": ООО "Издательство "Мир и Образование" 2008.

13. Воеводин В.В. Математические модели и методы в параллельныхпроцессах.-М.: Наука. Гл.ред. физ.-мат.лит., 1986.

14. Никаноров Н.В., Шандаров С.М. Волноводная фотоника. - С-Пб.: Изд-во ИTMO, 2008.

15. T.P. Morgan. Nvidia Rounds Out Pascal Tesla Accelerator Lineup. June 20, 2016 [Электронный ресурс]. Режим доступа: http://uww.nextplatform. com/2016/06/20/nvidia-rounds-pascal-tesla-accelerator-lineup.
- passive optical logic elements

- computational discipline on the readiness of operands

- conflict-free algorithms for processing information by processor elements connected to a multiprocessor environment.

Classes of tasks solved by photonic and electronic computers coincide.

The completed analysis and the obtained estimates demonstrate the possibility of achieving a peak performance by a photonic computer using radiation with a wavelength of $1530 \mathrm{~nm}, 10^{3}-10^{4}$ times greater than that achieved by modern electronic computing devices with equal energy consumed.

The use of technologies that ensure the use of ultraviolet radiation in a photonic computer with a wavelength of $100 \mathrm{~nm}$ allows the photonic computer to achieve Exaflop performance $\left(10^{18} \mathrm{op} / \mathrm{s}\right)$ per 100 watts of power.

The radiation with different wavelengths do not interact with each other. If the OLE is properly implemented in one photonic computer, several computational processes can be performed simultaneously, represented by light waves of different lengths. 